\title{
DIVERSITY OF MARINE FISH AND THEIR CONSERVATION STATUS IN PUSONG BAY, LHOKSEUMAWE CITY, ACEH PROVINCE, INDONESIA
}

\author{
ADRIAN DAMORA ${ }^{1, *}$, AGUNG S. BATUBARA $^{1}$, ZUHDI ZUHDI ${ }^{2}$, \\ YOKE HANY RESTIANGSIH ${ }^{3}$, FACHRUROZI AMIR ${ }^{2}$, \\ MUHAMMAD IRHAM ${ }^{2}$, NUR FADLI ${ }^{1}$, FIRMAN M. NUR ${ }^{4}$, \\ and RIZAL RIZAL ${ }^{5}$
}

\footnotetext{
${ }^{1}$ Department of Aquaculture, Faculty of Marine and Fisheries, Universitas Syiah Kuala, 23111 Banda Aceh, Indonesia

2 Department of Fishery Resources Utilization, Faculty of Marine and Fisheries, Universitas Syiah Kuala, 23111 Banda Aceh, Indonesia

${ }^{3}$ Research Institute for Marine Fisheries, Ministry of Marine Affairs and Fisheries Republic of Indonesia, 16912 Cibinong, Indonesia

${ }^{4}$ Doctorate Programme in Mathematics and Applied Sciences, Graduated Studies, Universitas Syiah Kuala, 23111 Banda Aceh, Indonesia

${ }^{5}$ Directorate of Marine and Fisheries - Aceh Program, WWF-Indonesia, 23244 Banda Aceh, Indonesia

* Corresponding author: adamora@unsyiah.ac.id
}

\section{ABSTRACT}

Marine fish have been decreasing in abundance over the last few decades due to environmental destruction and human exploitation The aim of this study was to produce an inventory of the fish in Pusong Bay, Lhokseumawe City, Aceh Province, Indonesia by means of an exploratory survey of the area. The data was analysed descriptively using tables and graphs. A total of 71 species of fish were identified belonging to 54 genera, 37 families and 15 orders. Fish belonging to the Perciformes dominated the area with 33 species or $46.48 \%$ of the total number of fish identified. Based on the IUCN red list status, $62 \%$ of the species recorded in this study are categorized as of Least Concern, 35\% Not Evaluated and 3\% Data Deficient. Based on CITES, 71 species of the fish in Pusong Bay are categorized as Not Evaluated. Current data on these fish is important for future evaluations of their status.

Keywords: bay; order; Pusong; species

\section{Introduction}

Bay waters are zones subject to high levels of human activity, such as industry, port facilities, tourism and fishing (Bunce et al. 1999; Walker 2001; Poulard and Léauté 2002; Wesley et al. 2016; Sahetapy et al. 2018), which result in sedimentation, pollution and erosion (Auernheimer and Chinchon 1997; Ruilian et al. 2008; Wei et al. 2008; Gao and Chen 2012). In addition, bays are habitats for marine organism and one of the main sources of livelihood for local communities (Deng and Jin 2000; Jin and Deng 2000; van-der-Meij et al. 2009; Zakaria and Rajpar 2015), which in Aceh is mainly fishing.

The coastline of Aceh province is $1865 \mathrm{~km}$ long and encompass $591,089 \mathrm{~km}^{2}$ of ocean, which is utilized by industries, port facilities and fisheries. Aceh also includes 663 islands in the Straits of Malacca and Indian Ocean (BPS Aceh 2019). One of the bays in this province is $\mathrm{Pu}$ song Bay, which is governed by the Lhokseumawe City Government.

Pusong Bay is in the Fisheries Management Area (FMA) 571 of the Republic of Indonesia, which includes the Straits of Malacca and Andaman Sea (KKP 2014). Around 3500 fishermen fish in this area and harvest on average 8944 tones/year (DKP Kota Lhokseumawe 2018). Based on this data, Pusong Bay is one of the best fishing grounds on the north coast of Aceh. Therefore, it is essential for the future management of the fisheries to have an inventory of the species of fish in this area.
There are inventories of the species of fish for several areas in Aceh, such as Aceh Besar Regency (Rizwan et al. 2017; Dekar et al. 2018; Dewiyanti et al. 2019; Nur et al. 2019a), Banda Aceh (Muchlisin et al. 2017a; Fadli et al. 2018; Perdana et al. 2018), Sabang (Rudi et al. 2009; Rudi et al. 2012), Pidie (Nasir et al. 2018), Central Aceh (Muchlisin et al. 2013) and South-West Aceh (Muchlisin et al. 2015; Batubara et al. 2017; Muchlisin et al. 2017b; Batubara et al. 2018; Irhami et al. 2018; Timorya et al. 2018; Nur et al. 2019b), but not for Pusong Bay, Lhokseumawe. Therefore, the aim of this study is to collect data that will be important for the management of fisheries and conservation of endangered species of fish in the future. In addition, the diversity of fish is a good indicator of the effect of climate change, environmental degradation and pollution in an area (Fausch et al. 1990; Schiemer 2000; Daufresne and Boet 2007; Brodeur et al. 2008; Villéger et al. 2010).

\section{Material and Methods}

This study was carried out from April to May 2019 at Teluk Pusong, Lhokseumawe City, Aceh Province, Indonesia (Fig. 1). Fish were sampled using a local fishing boat to sweep an area of the bay. A mini fish trawl with mesh size of 2 inches in the wing net, 1.5 inches in the body net and 0.5 inches in the cod end, was used. The Sparre and Venema (1992) equation was used to calculate fish stock abundance: 
$a=V \times t \times h r \times X 2 \times 1.852 \times 0.001$

$D=(1 / a) \times(c / f)$

Where:

$a$ - swept area $\left(\mathrm{km}^{2}\right)$,

$V$ - net pull velocity (knot),

$T$ - time for which the net was towed (hour),

$h r$ - head rope length $(\mathrm{m})$,

$X 2$ - head rope length fraction of 0.5 according to Pauly

(1980) as the width swept by trawl,

1.852 - conversion from miles to kilometres,

0.001 - conversion from meter to kilometres,

$D$ - fish stock abundance (ton $\mathrm{km}^{-2}$ ),

$c$ - catch rate $\left(\mathrm{kg} \mathrm{hr}^{-1}\right)$,

$f$ - escapement factor of 0.5 as an estimate of the proportion of fish in the swept area that were caught by the net (Saeger et al. 1976).

The data collected was analysed in the Laboratory of Ichthyology, Faculty of Marine and Fisheries, Universitas Syiah Kuala, Banda Aceh, Indonesia. This study used an explorative survey (Muchlisin and Siti-Azizah 2009) after identifying locations with a high abundances of fish using information provided by local fisherman. Fish caught were identified using Allen (2000), Schultz (2004), Vida and Kotai (2006), Ambak et al. (2010) and Kottelat (2013).

Samples were collected from several areas in Pusong Bay, the location of which was based on information from local fishermen. Sampling was carried out between 07:00 PM and 08:00 AM. Fish were caught using a mini trawl (net and pocket length of 6 meters). The gear was pulled randomly for 2 hours in a particular area of $\mathrm{Pu}$ song Bay at a depth between 8-40 meters. Hauling took 15 minutes during which the fish were grouped based on species and the mini trawl was set for fishing. The trawl was operated approximately 5 to 6 times per night.

Fish caught were processed in terms of total and standard length measurement using a digital caliper (Mitutoyo, CD-6CS. Error $=0.01 \mathrm{~mm}$ ) and weight using a digital scale (Toledo, AB-204. Error =0.01 g). Fish were documented using a digital camera (Nikon D5300). Fish samples were then preserved in $10 \%$ formaldehyde solution.

The threat status of the identified species of fish was determined by reference to the IUCN red list of threatened species website (https://www.iucnredlist.org/) and its trade status using the CITES website (https://checklist .cites.org/\#/en). Data was analysed descriptively by means of tables and graphs based on (Batubara et al. 2017) and compared with the results of similar studies.

Environmental data used in this study was obtained from Aqua-MODIS L3 8Day composite satellite images with a $4 \mathrm{~km}$ spatial resolution, which was downloaded from http://oceancolor.gsfc.nasa.gov. Chlorophyll-a and sea surface temperature (SST) data were analysed using the SeaDAS 7.5.3 program and visualized using QGIS 3.4.14.

\section{Results}

In this study, 71 species of fish were recorded in Pusong Bay, Lhokseumawe City (Table 1), belonging to 15 orders, 37 families and 54 genera (Table 2). The dominant group were those belonging to the order Perciformes, based on the number of families (14 families), genera (24 genera) and species (33 species) (Table 2). Based on the number of species, the family Carangidae in the order Perciformes dominated the bay with 8 species (Table 1).

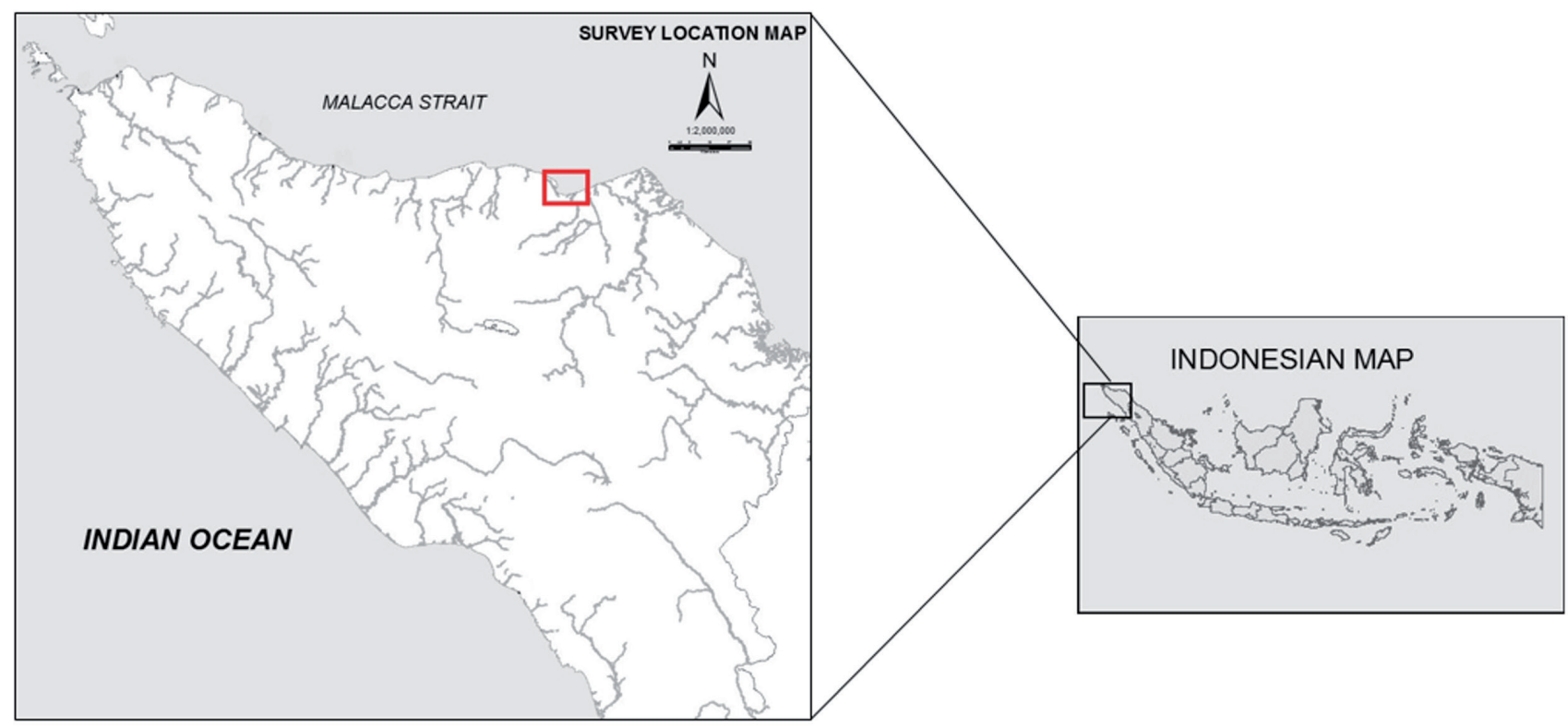

Fig. 1 Maps showing the location (red square) of Pusong bay, the site of this study. 
Table 1 Species of fish recorded in Pusong Bay, Lhokseumawe.

\begin{tabular}{|c|c|c|c|c|c|c|c|}
\hline No & Ordo & Family & Genus & Species & Common Name & $\begin{array}{c}\text { IUCN } \\
\text { Red List }\end{array}$ & CITES \\
\hline 1. & \multirow{2}{*}{ Aulopiformes } & \multirow{2}{*}{ Synodontidae } & \multirow{2}{*}{ Saurida } & Saurida gracilis & Gracile Lizardfish & LC & NE \\
\hline 2. & & & & Saurida undosquamis & Brush tooth Lizardfish & LC & NE \\
\hline 3. & Beloniformes & Hemiramphidae & Hemiramphus & Hemiramphus far & Black-Barred Halfbeak & NE & NE \\
\hline 4. & \multirow{4}{*}{ Clupeiformes } & Clupeidae & Sardinella & Sardinella gibbosa & Gold stripe Sardinella & LC & NE \\
\hline 5. & & \multirow{3}{*}{ Engraulidae } & Stolephorus & Stolephorus indicus & Indian Anchovy & LC & NE \\
\hline 6. & & & \multirow{2}{*}{ Thryssa } & Thryssa hamiltonii & Hamilton's Thryssa & LC & NE \\
\hline 7. & & & & Thryssa mystax & Moustached Thryssa & LC & NE \\
\hline 8. & Elopiformes & Megalopidae & Megalops & Megalops cyprinoides & Indo-pacific Tarpon & $\mathrm{DD}$ & NE \\
\hline 9. & \multirow{4}{*}{ Kurtiformes } & \multirow{4}{*}{ Apogonidae } & \multirow{4}{*}{ Apogon } & Apogon ellioti & Flag-in Cardinalfish & $\mathrm{NE}$ & NE \\
\hline 10. & & & & Apogon quadrifasciatus & Broad banded Cardinalfish & $\mathrm{NE}$ & NE \\
\hline 11. & & & & Apogon sp. & Cardinalfish & $\mathrm{NE}$ & NE \\
\hline 12. & & & & Apogon timorensis & Timor Cardinalfish & NE & NE \\
\hline 13. & Lophiiformes & Antennariidae & Antennarius & Antennarius striatus & Striated Frogfish & LC & NE \\
\hline 14. & Myliobatiformes & Dasyatidae & Himantura & Himantura toshi & Black-Spotted Whip ray & LC & NE \\
\hline 15. & \multirow{33}{*}{ Perciformes } & Ambassidae & Ambasis & Ambassis nalua & Scalloped Perch let & LC & NE \\
\hline 16. & & \multirow{8}{*}{ Carangidae } & Alectis & Alectis indica & Indian Thread fish & LC & NE \\
\hline 17. & & & \multirow{2}{*}{ Carangoides } & Carangoides ferdau & Blue Trevally & LC & NE \\
\hline 18. & & & & Carangoides uii & Coastal Trevally & LC & NE \\
\hline 19. & & & Caranx & Caranx sexfasciatus & Bigeye Trevally & LC & NE \\
\hline 20. & & & Scomberoides & Scomberoides lysan & Double spotted Queen fish & LC & NE \\
\hline 21. & & & Selaroides & Selaroides leptolepis & Yellow stripped scad & LC & NE \\
\hline 22. & & & tHe & Ulua aurochs & Silver mouth Trevally & LC & NE \\
\hline 23. & & & оाü & Ulua mentalis & Longrakered Trevally & LC & NE \\
\hline 24. & & Gerreidae & Gerres & Gerres longirostris & Strong spine Silver-Biddy & LC & NE \\
\hline 25. & & Gobiidae & Istigobius & Istigobius spence & Pearl Goby & LC & $\mathrm{NE}$ \\
\hline 26. & & \multirow{2}{*}{ Haemulidae } & Diagramma & Diagramma labiosum & Painted Sweetlips & LC & $\mathrm{NE}$ \\
\hline 27. & & & Pomadasys & Pomadasys kaakan & Javelin Grunter & $\mathrm{NE}$ & $\mathrm{NE}$ \\
\hline 28. & & \multirow{7}{*}{ Leiognathidae } & Gazza & Gazza minuta & Toothed Pony fish & LC & NE \\
\hline 29. & & & \multirow{3}{*}{ Leiognathus } & Leiognathus equulus & Common Pony fish & LC & NE \\
\hline 30. & & & & Leiognathus leuciscus & Whip fin Pony fish & LC & NE \\
\hline 31. & & & & Leiognathus splendens & Splendid Pony fish & LC & NE \\
\hline 32. & & & \multirow{3}{*}{ Secutor } & Secutor sp. & Pony fish & $\mathrm{NE}$ & NE \\
\hline 33. & & & & Secutor indicius & Pony fish & $\mathrm{NE}$ & $\mathrm{NE}$ \\
\hline 34. & & & & Secutor interruptus & Pig-Nosed Pony fish & $\mathrm{NE}$ & NE \\
\hline 35. & & \multirow{5}{*}{ Lutjanidae } & Etelis & Etelis carbunculus & Ruby Snapper & LC & $\mathrm{NE}$ \\
\hline 36. & & & \multirow{3}{*}{ Lutjanus } & Lutjanus lutjanus & Bigeye Snapper & LC & NE \\
\hline 37. & & & & Lutjanus apodus & Schoolmaster Snapper & LC & NE \\
\hline 38. & & & & Lutjanus fulviflamma & Dory Snapper & LC & NE \\
\hline 39. & & & Pristipomoides & Pristipomoides multidens & Gold banded Job fish & LC & $\mathrm{NE}$ \\
\hline 40. & & Mullidae & Upeneus & Upeneus sulphureus & Sulphur Goatfish & LC & NE \\
\hline 41. & & \multirow[b]{2}{*}{ Nemipteridae } & \multirow[b]{2}{*}{ Nemipterus } & Nemipterus isacanthus & Teardrop Threadfin Bream & NE & $\mathrm{NE}$ \\
\hline 42. & & & & Nemipterus nematophorus & $\begin{array}{l}\text { Double whip Threadfin } \\
\text { Bream }\end{array}$ & LC & NE \\
\hline 43. & & Polynemidae & Polydactylus & Polydactylus nigripinnis & Black fin Threadfin & NE & NE \\
\hline 44. & & Priacanthidae & Priacanthus & Priacanthus hamrur & Moon tail Bullseye & LC & $\mathrm{NE}$ \\
\hline 45. & & Sciaenidae & Johnius & Johnius amblycephalus & Bearded Croaker & $\mathrm{NE}$ & $\mathrm{NE}$ \\
\hline 46. & & Serranidae & Epinephelus & Epinephelus lanceolatus & Giant Grouper & DD & $\mathrm{NE}$ \\
\hline 47. & & Siganidae & Siganus & Siganus canaliculatus & White-Spotted Spine foot & LC & $\mathrm{NE}$ \\
\hline
\end{tabular}




\begin{tabular}{|c|c|c|c|c|c|c|c|}
\hline No & Ordo & Family & Genus & Species & Common Name & $\begin{array}{c}\text { IUCN } \\
\text { Red List }\end{array}$ & CITES \\
\hline 48. & \multirow{6}{*}{$\begin{array}{l}\text { Pleuronecti- } \\
\text { formes }\end{array}$} & Bothidae & $\begin{array}{l}\text { Grammatobo- } \\
\text { thus }\end{array}$ & $\begin{array}{l}\text { Grammatobothus poly- } \\
\text { ophthalmus }\end{array}$ & Three spot Flounder & LC & $\mathrm{NE}$ \\
\hline 49. & & Cynoglossidae & Paraplagusia & Paraplagusia bilineata & Double lined Tongue sole & $\mathrm{NE}$ & NE \\
\hline 50. & & \multirow{2}{*}{ Paralichthyidae } & \multirow{2}{*}{ Pseudorhombus } & Pseudorhombus arsius & Large tooth Flounder & $\mathrm{NE}$ & $\mathrm{NE}$ \\
\hline 51. & & & & Pseudorhombus sp. & Flounder & NE & NE \\
\hline 52. & & \multirow{2}{*}{ Psettodidae } & \multirow{2}{*}{ Psettodes } & Psettodes erumei & Indian Halibut & $\mathrm{NE}$ & NE \\
\hline 53. & & & & Psettodes sp. & Halibut & NE & NE \\
\hline 54. & Scombriformes & Sphyraenidae & Sphyraena & $\begin{array}{l}\text { Sphyraena novaehol- } \\
\text { landiae }\end{array}$ & Australian Barracuda & NE & NE \\
\hline 55. & \multirow{7}{*}{ Scorpaeniformes } & Platycephalidae & Inegocia & Inegocia harrisii & Harris's Flathead & $\mathrm{NE}$ & $\mathrm{NE}$ \\
\hline 56. & & \multirow{5}{*}{ Scorpaenidae } & Brachypterois & Brachypterois serrulatus & Saw cheek Scorpionfish & NE & NE \\
\hline 57. & & & Parascorpaena & Parascorpaena mcadamsi & McAdam's Scorpionfish & LC & NE \\
\hline 58. & & & Pterois & Pterois russelii & Plain tail Turkey fish & LC & $\mathrm{NE}$ \\
\hline 59. & & & Scorpaenodes & Scorpaenodes hirsutus & Hairy Scorpionfish & LC & NE \\
\hline 60. & & & Scorpaenopsis & Scorpaenopsis venosa & Raggy Scorpionfish & LC & NE \\
\hline 61. & & Synanceiidae & Erosa & Erosa erosa & Pitted Stonefish & LC & NE \\
\hline 62. & Siluriformes & Plotosidae & Plotosus & Plotosus lineatus & Striped Eel Catfish & $\mathrm{NE}$ & NE \\
\hline 63. & Syngnathiformes & Fistulariidae & Fistularia & Fistularia petimba & Red Cornet fish & LC & NE \\
\hline 64. & \multirow{5}{*}{$\begin{array}{l}\text { Tetraodon- } \\
\text { tiformes }\end{array}$} & Balistidae & Balistoides & Balistoides viridescens & Titan Triggerfish & $\mathrm{NE}$ & $\mathrm{NE}$ \\
\hline 65. & & \multirow{3}{*}{ Tetraodontidae } & Arothron & Arothron reticularis & Reticulated Pufferfish & LC & NE \\
\hline 66. & & & Carinotetraodon & Carinotetraodon lorteti & Redeye Puffer & LC & NE \\
\hline 67. & & & Lagocephalus & Lagocephalus lunaris & Lunar tail Puffer & LC & NE \\
\hline 68. & & Triacanthidae & Triacanthus & Triacanthus biaculeatus & Short-Nosed Tripod fish & $\mathrm{NE}$ & $\mathrm{NE}$ \\
\hline 69. & \multirow{3}{*}{ Trachiniformes } & \multirow{2}{*}{ Uranoscopidae } & \multirow{2}{*}{ Uranoscopus } & Uranoscopus cognatus & Yellowtail Stargazer & $\mathrm{NE}$ & $\mathrm{NE}$ \\
\hline 70. & & & & Uranoscopus kaianus & Kai Stargazer & $\mathrm{NE}$ & NE \\
\hline 71. & & Labridae & Xiphocheilus & Xiphocheilus typus & Blue-Banded Wrasse & LC & NE \\
\hline
\end{tabular}

Table 2 Classification of the 71 species of fish recorded in terms of the order, family, genus and species to which they belong.

\begin{tabular}{|c|c|c|c|c|c|c|c|}
\hline \multirow{2}{*}{ No. } & \multirow{2}{*}{ Order } & \multicolumn{2}{|c|}{ Family } & \multicolumn{2}{|c|}{ Genus } & \multicolumn{2}{|c|}{ Species } \\
\hline & & Number & $\%$ & Number & $\%$ & Number & $\%$ \\
\hline 1. & Aulopiformes & 1 & 2.70 & 1 & 1.85 & 2 & 2.82 \\
\hline 2. & Beloniformes & 1 & 2.70 & 1 & 1.85 & 1 & 1.41 \\
\hline 3. & Clupeiformes & 2 & 5.41 & 3 & 5.56 & 4 & 5.63 \\
\hline 4. & Elopiformes & 1 & 2.70 & 1 & 1.85 & 1 & 1.41 \\
\hline 5. & Kurtiformes & 1 & 2.70 & 1 & 1.85 & 4 & 5.63 \\
\hline 6. & Lophiiformes & 1 & 2.70 & 1 & 1.85 & 1 & 1.41 \\
\hline 7. & Myliobatiformes & 1 & 2.70 & 1 & 1.85 & 1 & 1.41 \\
\hline 8. & Perciformes & 14 & 37.84 & 24 & 44.44 & 33 & 46.48 \\
\hline 9. & Pleuronectiformes & 4 & 10.81 & 4 & 7.41 & 6 & 8.45 \\
\hline 10. & Scombriformes & 1 & 2.70 & 1 & 1.85 & 1 & 1.41 \\
\hline 11. & Scorpaeniformes & 3 & 8.11 & 7 & 12.96 & 7 & 9.86 \\
\hline 12. & Siluriformes & 1 & 2.70 & 1 & 1.85 & 1 & 1.41 \\
\hline 13. & Syngnathiformes & 1 & 2.70 & 1 & 1.85 & 1 & 1.41 \\
\hline 14. & Tetraodontiformes & 3 & 8.11 & 5 & 9.26 & 5 & 7.04 \\
\hline 15. & Trachiniformes & 2 & 5.41 & 2 & 3.70 & 3 & 4.23 \\
\hline Total & & 37 & 100 & 54 & 100 & 71 & 100 \\
\hline
\end{tabular}

European Journal of Environmental Sciences, Vol. 10, №. 2 


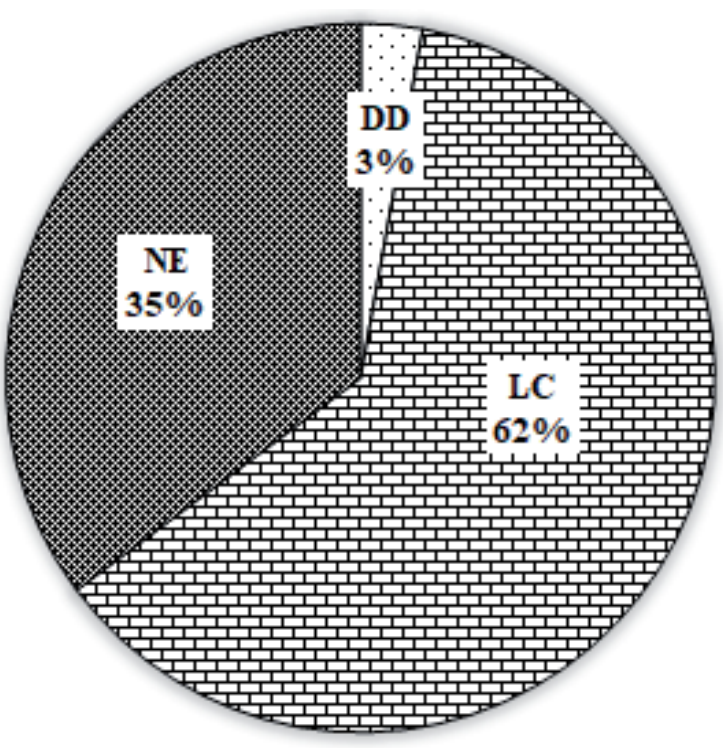

Fig. 2 Pie diagram of the IUCN red list status of the 71 species of fish species caught at Teluk Pusong, where DD is data deficient, LC least concern and NE not evaluated.

Threat status of the 71 species of fish in Pusong Bay based on The IUCN Red List indicates that $62 \%$ are categorized as of Least Concern (LC), 35\% Not Evaluated (NE) and 3\% as Data Deficient (DD) (Fig. 2). Moreover, based on the Convention on International Trade in Endangered Species (CITES), all of the species are categorized as Not Evaluated (Table 1).

The mini fish trawl used in this study was used to sweep an area of $34.42 \mathrm{~km}^{2}$ and caught $70.6 \mathrm{~kg}$ of fish. This indicates that the fish stock in Pusong Bay is
0.065 tonnes $\mathrm{km}^{-2}$. SST and chlorophyll concentrations also influence the abundance of fish in these waters. SST within Pusong Bay ranged between $30.9-31.1^{\circ} \mathrm{C}$ (Fig. 3) and the chlorophyll concentration between $2-4 \mathrm{mg} \mathrm{m}^{-3}$ (Fig. 4).

\section{Discussion}

The 71 species of fish collected in Pusong Bay, Lhokseumawe City (Table 2) belonged to 15 orders, which is higher than that recorded in other areas in Aceh Province, such as Simeulue Island (12 orders) (Batubara et al. 2017; Batubara et al. 2018), Meurebo River (7 orders) and Mifa Bersaudara Inc. Area (7 orders) in the West Aceh Regency (Irhami et al. 2018; Nur et al. 2019b), Aceh River (12 orders) in the Aceh Province (Dekar et al. 2018), Sabee River in the Aceh Jaya Regency (Timorya et al. 2018) and Lhoknga and Lhok Mata Ie Coast (8 orders) in the Aceh Besar Regency (Nur et al. 2019a). Thus based on the number of orders of fish, there is a higher diversity fish in the bay than in the river and coastal waters in Aceh Province.

A higher number of families of fish (37) were recorded in Pusong Bay than at other locations in Aceh such as Simeulue Island (26 families) (Batubara et al. 2017) and Lhoknga and Lhok Mata Ie Coast in the Aceh Besar Regency (11 families) (Nur et al. 2019a). However, the number of families of marine fish recorded in Pusong Bay is lower than that of families of freshwater fish in Aceh Province, which is 41 families (Muchlisin and Si-

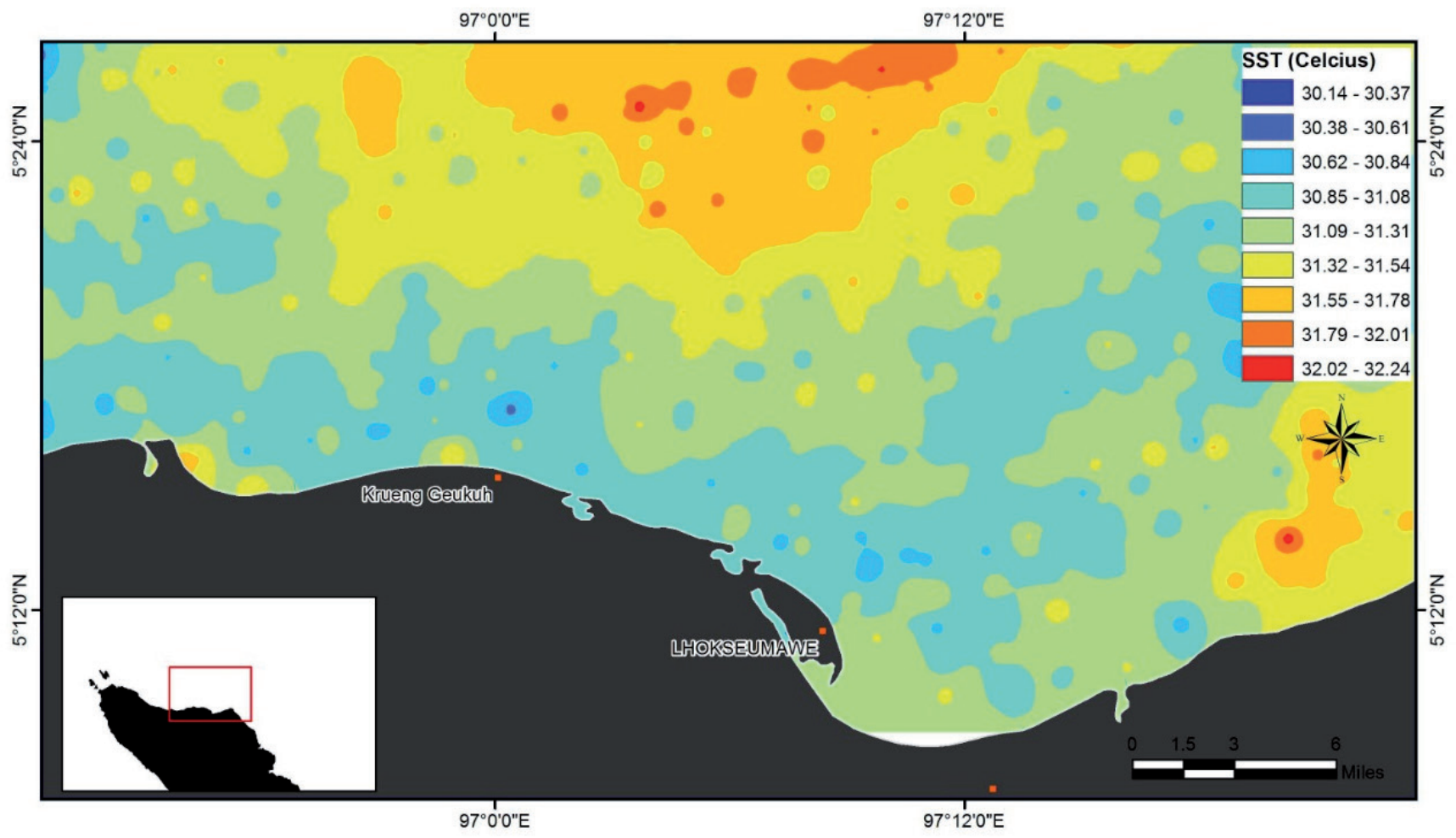

Fig. 3 Map showing sea surface temperatures (SST) in the Pusong Bay when the fish were sampled. 


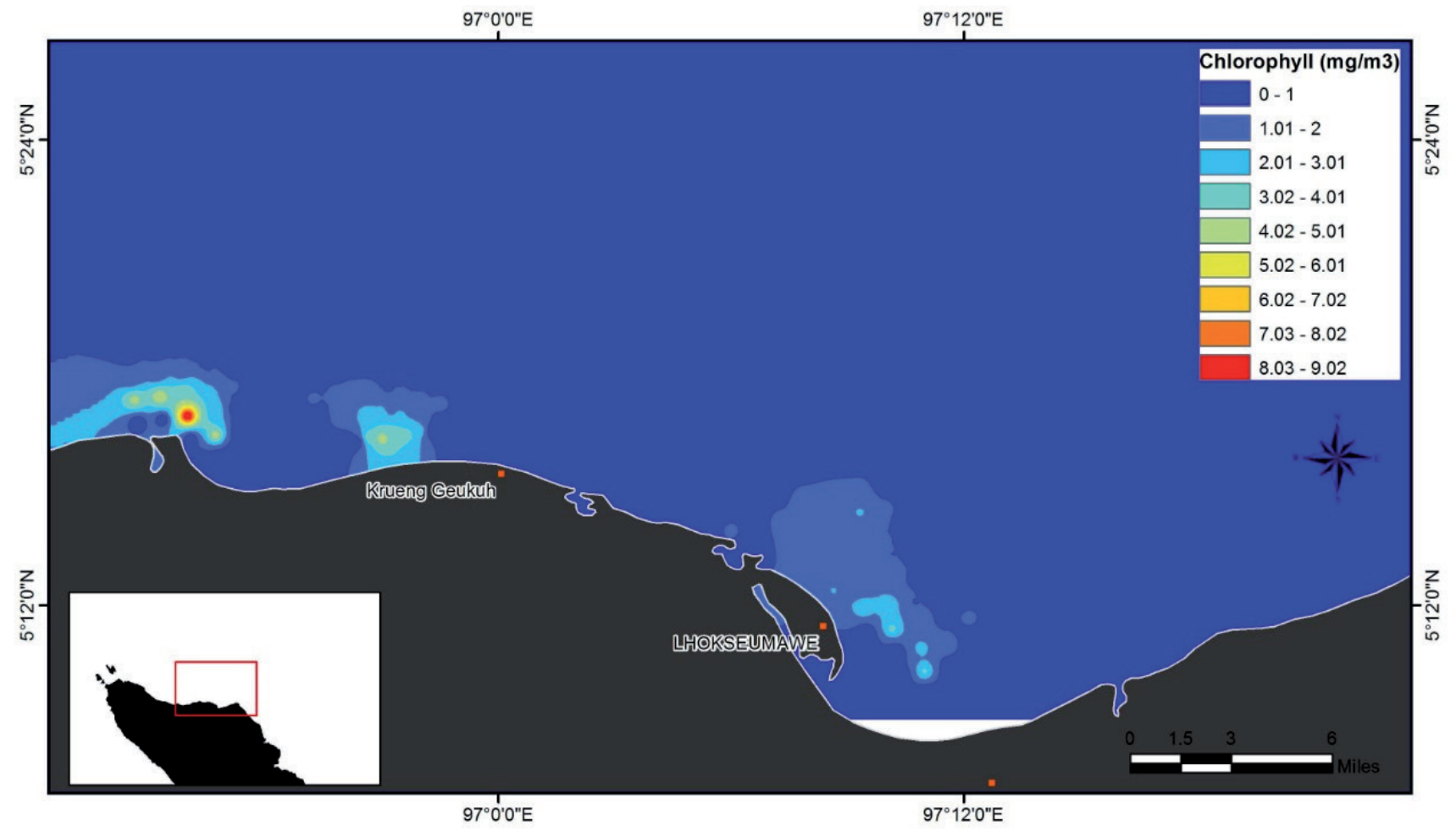

Fig. 4 Map showing the concentrations of chlorophyll recorded in Pusong Bay when the fish were sampled.

ti-Azizah 2009). The number of species of fish recorded in Pusong Bay (71) is also lower than the number recorded in several other areas in Aceh Province, such as Aceh River (44) (Dekar et al. 2018), Meureubo River (32) (Irham et al. 2018), Lhoknga and Lhok Mata Ie Coast (25) (Nur et al. 2019a) and Sabee River (12) (Timorya et al. 2018).

The order Perciformes dominated Pusong Bay in terms of the number of species (33) and percentage composition of the total catch $(46.48 \%)$. The same order of fish dominates in other areas such as Simeulue Island (67 species) (Batubara et al. 2017) and Aceh River (20 species) (Dekar et al. 2018). However, the order Cypriniformes dominates in area such as Rawa Teripa waters in Nagan Raya Regency (19\% of all species caught) (Muchlisin et al. 2015), Mifa Bersaudara Inc. Area (39\%) (Nur et al. 2019b) and Meureubo River in West Aceh Regency (12.5\%) (Irhami et al. 2018).

Based on the IUCN red list status, $62 \%$ of the fish in Pusong Bay are categorized as of Least Concern (LC) and $38 \%$ as Data Deficient (DD) or Not Evaluated (NE). LC is attributed to species not listed in a higher threat category, which are usually widely distributed and abundant (Rodrigues et al. 2006). DD is attributed to species for which there is little or no data on their distribution or abundance (Gärdenfors et al. 2001). While NE is attributed to species for which the threat risk has not been evaluated (Hoffmann et al. 2008). Based on CITES, the 71 species of fish recorded in Pusong Bay have not been evaluated (CITES 2020).

A precautionary approach is recommended for managing the resources of fisheries that have a NE status.
This approach aims to protect fish from both growth and recruitment overfishing (Lessa and Duarte-Neto 2004; Damora and Wagiyo 2012; Damora and Baihaqi 2013; Damora et al. 2018a, b).

The abundance of the fish stock recorded in this study is relatively low, compared with other studies in the Java Sea (Badrudin et al. 2011) that report fish stocks of 2.7-3.1 tonnes $\mathrm{km}^{2}$. East and west monsoons influence the abundance of fish in the Pusong Bay, as during the east monsoon demersal fish tend to gather in shore due to the murky waters associated with the strong southeast wind, which create a whirlpool of schools of fish as a result of an interaction between the water currents and fish (Badrudin et al. 2011). Meanwhile, this study was conducted in the transitional season between the west and east monsoon, which created strong currents and waves within Pusong Bay.

The average gradient in SST in tropical waters is about $0.3-1{ }^{\circ} \mathrm{C}$ (Choudhury et al. 2007). SST gradient affects change in the water resulting in upwelling and accumulations of plankton usually affects fish behaviour, as they respond by modifying their metabolism, spawning, migrating, increasing food consumption and the salt concentration in their bodies (Laurs et al. 1984; Arnone 1987).

The concentration of chlorophyll in Pusong Bay is lower than in other areas in the Andaman Sea, such as the coastal waters of Bangladesh, Myanmar, Thailand and Malaysia. The Andaman Sea and Pusong Bay are located in the same bio-ecoregion and the concentration of chlorophyll in these areas is between 5-15 $\mathrm{mg} \mathrm{m}^{-3}$. In addition, Suwannathatsa et al. (2012) 
report a concentration of $15-30 \mathrm{mg} \mathrm{m}^{-3}$ in the Malacca Straits.

February and May are the transition period between the west to east monsoon season in which the divergence of Ekman transport, equatorial Kelvin waves and Rossby waves create a strong current that spreads through the Nicobar Islands within the Andaman Sea. This strong current is neutralized during the transition period between the northeast and southwest monsoons, which results in murky conditions and an increase in the average SST (Suwannathatsa et al. 2012). During this transition, there is no runoff of rainwater into the bay, which along with the turbulence result in a decrease in the concentration of chlorophyll to its lowest level (Suwannathatsa and Wongwises 2013). Fish generally are only abundant where there are high concentrations of chlorophyll, which is an indicator of rich nutrient water where fish are likely to be abundant (Santos 2000; Zainuddin 2011).

\section{Conclusion}

In conclusion, the order Perciformes dominated the area with the highest number of species of fish. Based on the IUCN red list status, $62 \%$ of the species of fish are of Least Concern, 35\% Not Evaluated and 3\% Data Deficient. Based on CITES the 71 species of fish in $\mathrm{Pu}$ song Bay are categorized as Not Evaluated. Data on these species of fish are important in terms of evaluating their status in the future.

\section{Acknowledgements}

The authors would like to thank the WWF-Indonesia Aceh Program for supporting this research. We are also grateful to Ade Fitra Aprilian for his cooperation during the sampling of fish.

\section{REFERENCES}

Allen G (2000) Marine fishes of south-east Asia. Australia: Published by Periplus Editions Ltd.

Ambak MA, Isa MM, Zakaria MZ, Ghaffar MA (2010) Fishes of Malaysia. Malaysia: Published by Universiti Malaysia Terengganu.

Arnone RA (1987) Satellite-derived colour-temperature relationship in the Alboran Sea. Remote Sens Environ 23: 417-437.

Auernheimer C, Chinchon S (1997) Calcareous skeletons of sea urchins as indicators of heavy metals pollution: Portman Bay, Spain. Environ Geol 29: 78-83.

Badrudin, Aisyah, Ernawati T (2011) Demersal fish stock abundance in the Java Sea sub areas. J Lit Perikan Ind 17: 11-21.

Batubara AS, Muchlisin ZA, Thamren MY, Usnardi U, Fadli N (2017) Check list of marine fishes from Simeulue Island waters, Aceh Province, Indonesia. Aceh J Anim Sci 2: 77-84.
Batubara AS, Abdan M, Muhammad Z, Putra NF, Muchlisin ZA (2018) Peripheral fishes in the Estuary of Simeulue Island, Indonesia. IOP Publishing: IOP Conf Series: Earth Environ Sci 216: 012011.

BPS Aceh (2019) Provinsi Aceh dalam angka 2019. Indonesia: Published by Badan Pusat Statistik Provinsi Aceh. [in Indonesian]

Brodeur RD, Peterson WT, Auth TD, Soulen HL, Parnel MM, Emerson AA (2008) Abundance and diversity of coastal fish larvae as indicators of recent changes in ocean and climate conditions in the Oregon upwelling zone. Mar Ecol Prog Ser 366: 187-202.

Bunce L, Gustavson K, Williams J, Miller M (1999) The human side of reef management: a case study analysis of the socioeconomic framework of Montego Bay Marine Park. Coral Reefs 18: 369-380.

Choudhury SB, Jena B, Rao MV, Rao KH, Somvanshi VS, Gulati DK, Sahu SK (2007) Validation of integrated potential fishing zone (IPFZ) forecast using satellite based chlorophyll and sea surface temperature along the east coast of India. Int J Remote Sens 28: 2683-2693.

CITES (2020) Checklist of CITES species. https://checklist.cites .org/\#/en. Accessed 15 December 2019.

Daufresne M, Boet P (2007) Climate change impacts on structure and diversity of fish communities in rivers. Glob Chan Biol 13: 2467-2478.

Damora A, Baihaqi B (2013) Size distribution and population parameters of yellowfin tuna (Thunnus albacares) in Banda Sea. Bawal 5: 59-65.

Damora A, Wagiyo K (2012) Population parameters of Spilgler's Mullet (Valamugil speigleri) as an intensity indicator of utilization of estuaries waters resources in Pemalang, Central Java. Bawal 4: 91-96.

Damora A, Ariyogagautama D, Wahju RI, Susanto H, Wang J (2018a) Short communication: Growth and mortality rate of black pomfret Parastromateus niger (Bloch, 1795) and silver pomfret Pampus argenteus (Euphrasen, 1788) in Paloh Waters, West Kalimantan, Indonesia. Biodiversitas 19: 2247-2251.

Damora A, Fikri IA, Teneu IM, Lestari P, Iqbal TH, Yusuf M (2018b) Reproductive biology of three reef fish species from Kei Islands, Southeast Maluku, Indonesia. IOP Publishing. IOP Conf Series. Earth Environ Sci 216: 012002.

Dekar M, Sarong MA, Batubara AS, Muchlisin ZA (2018) Ichthyofauna of Aceh River, Aceh Province, Indonesia. IOP Publishing: IOP Conf Series: Earth Environ Sci 216: 012024.

Deng J, Jin X (2000) Study on fishery biodiversity and its conservation in Laizhou Bay and Yellow River estuary. Zool Res 21: $76-82$.

Dewiyanti I, Syahputra R, Ulfah M, Yunita Y (2019) Fish diversity and abundance in GROPOZAG construction in Ujong Batee waters, Aceh Besar District, Indonesia. IOP Publishing: IOP Conf Series. Earth Environ Sci 348: 012080.

DKP Kota Lhokseumawe (2018) Data perikanan tangkap Kota Lhokseumawe. Indonesia: Published by Dinas Kelautan dan Perikanan Kota Lhokseumawe, (in Indonesian).

Fadli N, Muchlisin ZA, Sofyan H, El-Rahimi SA, Dewiyanti I, Pratama FO, Mustari TR, Siti-Azizah MN (2018) The composition of reef-associated fishes in Ulee Lheue breakwater Banda Aceh, Aceh, Indonesia. IOP Publishing: IOP Conf Series. Earth Environ Sci 216: 012021.

Fausch KD, Lyons JR, Karr JR, Angermeier PL (1990) Fish communities as indicators of environmental degradation. Am Fish Soc Symp 8: 123-144.

Gao X, Chen CTA (2012) Heavy metal pollution status in surface sediments of the coastal Bohai Bay. Water Res 46: 1901-1911. 
Gärdenfors U, Hilton-Taylor C, Mace GM, Rodríguez JP (2001) The application of IUCN Red List criteria at regional levels. Cons Biol 15: 1206-1212.

Hoffmann M, Brooks TM, Da-Fonseca GAB, Gascon C, Hawkins AFA, James RE, Langhammer P, Mittermeier RA, Pilgrim JD, Roddrigues ASL, Silva JMC (2008) Conservation planning and the IUCN Red List. Endang Spec Res 6: 113-125.

Irhami S, Fithri A, Batubara AS, Muchlisin ZA (2018). Fish fauna of Meureubo River, Aceh Barat District, Indonesia. IOP Publishing: IOP Conf Series. Earth Environ Sci 216: 012023.

IUCN (2020) The IUCN red list of threatened species. https:// www.iucnredlist.org/. Accessed 15 December 2019.

Jin X, Deng J (2000) Variations in community structure of fishery resources and biodiversity in the Laizhou Bay, Shandong. Chinese Biodiv 8: 65-72.

KKP (2014) Peraturan Menteri Kelautan dan Perikanan Republik Indonesia Nomor 18/PERMEN-KP/2014 tentang wilayah pengelolaan perikanan Negara Republik Indonesia. Jakarta: Kementerian Kelautan dan Perikanan. [in Indonesian]

Kottelat M (2013) The fishes of the inland waters of Southeast Asia: a catalogue and core bibliography of the fishes known to occur in freshwaters, mangroves and estuaries. Raffles Bull Zool 27: 1-663.

Laurs RM, Fielder PC, Montgomery DR (1984) Albacore Tuna catch distribution relative to environmental features observed from satellite. Deep-Sea Res 31: 1085-1099.

Lessa R, Duarte-Neto P (2004) Age and growth of yellowfin tuna (Thunnus albacares) in the Western Equatorial Atlantic, using dorsal fin spines. Fish Res 69: 157-170.

Muchlisin ZA, Siti-Azizah MN (2009) Diversity and distribution of freshwater fishes in Aceh waters, northern Sumatra Indonesia. Int J Zool Res 5: 62-79.

Muchlisin ZA, Thomy Z, Fadli N, Sarong MA, Siti-Azizah MN (2013) DNA barcoding of freshwater fishes from Lake Laut Tawar, Aceh Province, Indonesia. Acta Ichthyol Piscat 43: 21-29.

Muchlisin Z, Akyun Q, Halim A, Rizka S, Sugianto S, Fadli N, Siti-Azizah M (2015) Ichthyofauna of Tripa peat swamp forest, Aceh province, Indonesia. Check list 11: 1-9.

Muchlisin ZA, Fransiska V, Muhammadar AA, Fauzi M, Batubara AS (2017a) Length-weight relationships and condition factors of the three dominant species of marine fishes caught by traditional beach trawl in Ulelhee Bay, Banda Aceh City, Indonesia. Croatian J Fish 75: 104-112.

Muchlisin ZA, Nurfadillah N, Arisa II, Rahmah A, Putra DF, Nazir M, Zulham A (2017b) Fish fauna of Lake Lauik Tawar and Lake Laulo, Simeulue Island, Indonesia. Biodiversitas 18: 752-757.

Nasir M, Munira M, Muchlisin ZA (2018) Fish fauna in the Krueng Geumpang River, Indonesia. IOP Publishing: IOP Conf Series. Earth Environ Sci 139: 012023.

Nur FM, Batubara AS, Perdana AW, Eriani K, Muchlisin ZA (2019a) Checklist of coral fishes in Lhoknga and Lhok Mata Ie Beaches, Aceh Besar, Indonesia. IOP Publishing: IOP Conf Series. Earth Environ Sci 348: 012104.

Nur FM, Batubara AS, Abdan M, Syukran M, Muchlisin ZA (2019b) Ichthyofauna in coal mining area of Mifa Bersaudara Company, Aceh Barat District, Indonesia. IOP Publishing: IOP Conf Series. Earth Environ Sci 348: 012014.

Pauly D (1980) A selection of simple methods for the assessment of tropical fish stocks. French: FAO Fish. Circ.

Perdana AW, Batubara AS, Aprilla RM, Nur FM, Iqbal TH (2018) Length-weight relationships of three popular fishes from Banda Aceh, Indonesia. IOP Publishing: IOP Conf Series. Earth Environ Sci 216: 012053.
Poulard JC, Léauté JP (2002) Interaction between marine populations and fishing activities: temporal patterns of landings of La Rochelle trawlers in the Bay of Biscay. Aqua Liv Res 15: 197-210.

Rizwan T, Nasution TK, Dewiyanti I, Elrahimi SA, Putra DF (2017) Fish diversity in the east coastal waters area of Aceh Besar District, Indonesia. AACL Bioflux 10: 1180-1185.

Rodrigues AS, Pilgrim JD, Lamoreux JF, Hoffmann M, Brooks TM (2006) The value of the IUCN Red List for conservation. Trends Ecol Evol 21: 71-76.

Rudi E, Elrahimi SA, Kartawijaya T, Herdiana Y, Setiawan F, Pardede ST, Cambell ST, Tamelander J (2009) Reef fish status in northern Acehnese reef based on management type. Biodiversitas 10: 88-93.

Rudi E, Iskandar T, Fadli N, Hidayati H (2012) Impact of mass coral bleaching on reef fish community and fishermen catches at Sabang, Aceh Province, Indonesia. AACL Bioflux 5: 309-320.

Ruilian YU, Xing Y, Yuanhui ZHAO, Gongren HU, Xianglin TU (2008) Heavy metal pollution in intertidal sediments from Quanzhou Bay, China. J Environ Sci 20: 664-669.

Saeger J, Martosubroto P, Pauly D (1976) First report of the Indonesian-German demersal fisheries project (Result of a trawl survey in the Sunda Shelf area). Jakarta, Marine Fisheries Research Report (Special report). Contribution of the Demersal Fisheries Project No. 1.

Sahetapy D, Retraubun ASW, Bengen DG, Abrahamsz J (2018) Coral reef fishes of Tuhaha Bay, Saparua Island, Maluku province, Indonesia. Int J Fish Aqua Stud 6: 105-109.

Santos AMP (2000) Fisheries oceanography using satellite and airborne remote sensing methods: a review. Fish Res 49: 1-20.

Schiemer F (2000) Fish as indicators for the assessment of the ecological integrity of large rivers. Hydrobiologia 422: 271-278.

Schultz K (2004) Ken Schultz's field guide to saltwater fish. USA: John Wiley and Sons.

Sparre P, Venema SC (1992) Introduction to Tropical Fish Stock Asseessment Part 1. Manual. FAO Fish Tech Pap No 1: 376 pp.

Suwannathatsa S, Wongwises P, Vongvisessomjai S, Wannawong W, Saetae D (2012) Phytoplankton tracking by oceanic model and satellite data in the Bay of Bengal and Andaman Sea. ICBFS 2012, Bangkok, Thailand. Procedia APCBEE 2: 183-189.

Suwannathatsa S, Wongwises P (2013) Chlorophyll distribution by oceanic model and satellite data in the Bay of Bengal and Andaman Sea. Int J Oceanogr Hydrobiol 42: 132-138.

Timorya Y, Abdullah A, Batubara AS, Muchlisin ZA (2018) Conservation and economic status fishes in the Krueng Sabee River, Aceh Jaya District, Aceh Province, Indonesia. IOP Publishing: IOP Conf Series. Earth Environ Sci 216: 012044.

van-der-Meij SE, Moolenbeek RG, Hoeksema BW (2009) Decline of the Jakarta Bay molluscan fauna linked to human impact. Mar Poll Bull 59: 101-107.

Vida A, Kotai T (2006) 365 fish. China: Published by Konemann. Villéger S, Miranda JR, Hernández DF, Mouillot D (2010) Contrasting changes in taxonomic vs. functional diversity of tropical fish communities after habitat degradation. Ecol Applic 20: $1512-1522$.

Walker R (2001) Industry builds the city: The suburbanization of manufacturing in the San Francisco Bay Area, 1850-1940. J Hist Geogr 7: 36-57.

Wei M, Yanwen Q, Zheng B, Zhang L (2008) Heavy metal pollution in Tianjin Bohai bay, China. J Environ Sci 20: 814-819.

Wesley D, O'Connor SUE, Fenner JN (2016) Re-evaluating the timing of the Indonesian trepang industry in north-west Arn- 
hem Land: chronological investigations at Malara (Anuru Bay A). Archaeol Ocean 51: 169-195.

Zainuddin M (2011) Skipjack tuna in relation to sea surface temperature and chlorophyll-a concentration of Bone Bay using remotely sensed satellite data. J Ilmu Tek Kel Trop 3: 82-90.
Zakaria M, Rajpar MN (2015) Assessing the fauna diversity of Marudu Bay mangrove forest, Sabah, Malaysia, for future conservation. Diversity 7: 137-148. 